\title{
Morphometric study of Nigerian indigenous hen treatment with clomiphene citrate (clomid $^{\circledR}$ )
}

Urom, S. M. O. C. Dauda, E. and Onunkwo, D. N.

Department of Animal Breeding and Physiology, College of Animal Science and Animal Production, Michael Okpara University of Agriculture, Umudike, Umuahia, Abia State,

Nigeria

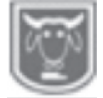

Abstract
Department Animal Production Technology,

Federal College of Agriculture, Ishiagu, Ebonyi State Nigeria.

Corresponding Author: scholarurom@yahoo.com, and

The study was carried out to know the effect of Clomiphene citrate on the reproductive organ weight of Nigerian indigenous hens. Forty-Eight (48) matured hens (26 weeks old) were used for this trial. The hens were randomly divided into four (4) treatment groups of 12 birds per treatment and further replicated into three (3) giving 4 birds per replicate in a completely randomized design and clomiphene citrate (Clomid ${ }^{\mathbb{B}}$ ) was administered at $0 \mathrm{mg}, 10 \mathrm{mg}, 20 \mathrm{mg}$ and $30 \mathrm{mg}$ levels for 5 days represented as $T_{1}, T_{2}, T_{3}$ and $T_{4}$ respectively. Treatment $t_{1}\left(T_{1}\right)$ contained no clomiphene citrate, served as the control. The birds were fed ad libitum with breeders mash and water served throughout the duration of the study. From the result recorded in this experiment on the reproductive organ weight, there were significant differences $(P<0.05)$ ranked among the treatment groups in all the parameters measured. Treatment ${ }_{3}\left(T_{3}\right)(85.30 \mathrm{~g})$ ranked highest in the experiment on the full reproductive organ weight, followed by $T_{1}(85.01)$. Treatment ${ }_{2}\left(T_{2}\right)$ recorded the least value of $80.02 \mathrm{~g}$ in the full reproductive organ weight, Treatment $T_{1} T_{1}$ recorded the highest value (18.02) in left Oviduct, paired Oviduct (28.03g), left Ovary and paired Ovary (50.00g), while the least value in $T_{2}$ were recorded as follows: (12.75g), (24.30g), (42.00g) and (47.00g) in left Oviduct, paired Oviduct, left Ovary and Paired Ovary respectively. from the above measured parameters, it could be deduced that at $20 \mathrm{mg}$ clomiphene citrate administration, the reproductive organ weight is enhanced which means that under dosage of 10mg and over dosage of $30 \mathrm{mg}$ is not encouraged to the reproductive organ weight of Nigerian indigenous hens.

Key word: Clomiphene citrate, Morphometric weight, Reproductive Organs

\section{Introduction}

The poultry industry has become the predominant source of protein in the diet of the populace of most developed and developing countries (Oyewunmi et al., 2001). Nigeria like most other developing nations is faced with problems of insufficient food production and protein deficiency (Okoye et al., 1991). Olayemi (1996) reported that there is low level of animal protein consumption in Nigeria. The internationally recommended per capital animal protein level consumed in Nigeria is 7.0g (Geoff and Bernet 1995). This shortage of high protein food from animal source in diet of Nigeria citizens is a serious problem that needs urgent attention.

Poultry products are widely accepted for human consumption and also have quick returns on capital investment (Alabi et al., 2016) and it is an important segment of the food industry that provides meat and egg for human consumption. Poultry production plays a significant role in national economic development. According to Okonkwo and Akobuo 


\section{Morphometic study of Nigerian indigenous hen treatment with clomiphene citrate (clomid ${ }^{\circledR}$ )}

(2001), about $10 \%$ of Nigerian population is engaged in poultry production. Mostly on subsistence and small medium sized farms. Indigenous chicken constitute $80 \%$ of the 120 million poultry types raised in the rural areas in Nigeria (RIM, 1992). They are selfreliant and hardly birds with the capacity to withstand harsh weather conditions and adapt to adverse environment. Despite all these qualities, it is observed that the indigenous chicken are not in use the way it should as a result of extensive and random distribution of exotic breeds by both governmental and non-governmental organization which is believed to have diluted the indigenous genetic stock. If this continuous the gene pool of the indigenous genetic stock could be lost in the near future before they are described or studied.

This threat is in line with the FAO report (FAO, 1999), which states that animal genetic resources in developing countries in general are being eroded through the rapid transformation of the agricultural system, in which the main cause of the loss of indigenous breeds is the indiscriminate introduction of exotic genetic resources before proper characterization, utilization and conservation of indigenous genetic resources. In view of this, the indigenous breed or livestock needs specialized production, in order to improve their production. There is need for more practicable and controlled method of production. Naidheardt (1992) stated that higher specialized animal requires specialization in management such management include Artificial insemination and use of fertility/hormonal drugs like Clomiphene citrates to encourage reproduction in livestock as it has been reported by Terbalance and Hunton (2000) and Pereira et al. (2000). Clomiphene citrate is a non-steroidal, antiestrogen which possesses the qualities of weak oestrogenic properties. It has been used to induce ovulation in cases of amenorrhea and Oligomenorrhea (Greenblatt et al., 1961; Charles et al., 1963; Roy et al., 1963; Riley and Evans, 1964). It has also been successfully used in the treatment of several clinical complications involving endometrial hyperplasia, and precocious puberty in human female (Charles, et al., 1963; while Law, 1963; Kaiser, 1963). Drugs especially gonadotrophins have been used extensively to boost reproduction in other classes of livestock as reported in literatures. A lot of these treatments have evidently produced positive results in female goats, sheep and rabbits. Iheukwumere (2005)reported the effectiveness of clomid in super Ovulation in WAD goat which showed that an excellent result at higher dose of $0.4 \mathrm{mls}$.

It is believed that the result of these studies involving the use of Clomiphenecitrate in improving the reproduction organ weight would provide or facilitate better understanding of Nigeria local chicken with the view to enhancing their condition to improve the livelihood of farmers.

\section{Materials and methods Study area}

The study was carried out in the poultry unit of the teaching and research farm of Michael Okpara University of Agriculture, Umudike located within the rain-forest agro-ecological zone of South-Eastern Nigeria. The area is on latitude $05^{\circ} 28^{\prime}$ North, longitude $07^{\circ} 33^{\prime}$ East and at an altitude of $122 \mathrm{~m}$ above sea level. The location has annual precipitation range of $1700-2000 \mathrm{~mm}$, average temperature range of $22-28^{\circ} \mathrm{c}$ and average relative humidity of $55 \%$. The experiment involves 48 matured, normal feathered Nigerian indigenous hens. The birds were purchased from an open market in Umuahia North local Government of Abia state.

The previous management background of 
the birds were not known, so they were housed in battery cage, quarantined, dewormed and vaccinated to boost their immune system against any disease.

Breeders mash diet was fed to the birds for the duration of the experiments (30 days) while clean water was served. The 48 hens were divided into 4 treatment groups, and each treatment group had 12 birds coded $\mathrm{T}_{1}$, $\mathrm{T}_{2}, \mathrm{~T}_{3}$ and $\mathrm{T}_{4}$. These groups were further replicated into 3 replicates of 4 birds per replicate in a completely randomized. These birds received 4 levels of clomiphene citrate (clomid) as treatments. The levels of clomiphene citrate were $0 \mathrm{mg}, 10.00 \mathrm{mg}$, $20 \mathrm{mg}$ and $30.00 \mathrm{mg}$ represented as $\mathrm{T}_{1}, \mathrm{~T}_{2}, \mathrm{~T}_{3}$ and $\mathrm{T}_{4}$ respectively.Treatment one $\left(\mathrm{T}_{1}\right)$ which contained no clomid served as the control. The clomiphene citrate received was given through water. This was administered for 5 days.

Table 1: Levels of clomiphene citrate received by birds in each treatment groups

\begin{tabular}{lllll}
\hline DAYS & $\mathbf{T}_{\mathbf{1}}$ & $\mathbf{T}_{\mathbf{2}}$ & $\mathbf{T}_{\mathbf{3}}$ & $\mathbf{T}_{\mathbf{4}}$ \\
\hline Day 1 & 0 & 10 & 20 & 30 \\
Day2 & 0 & 10 & 20 & 30 \\
Day3 & 0 & 10 & 20 & 30 \\
Day4 & 0 & 10 & 20 & 30 \\
Day5 & 0 & 10 & 20 & 30 \\
\hline
\end{tabular}

The model is represented as follows:

$\mathrm{Y}_{\mathrm{ij}}=\mu+\mathrm{G}_{\mathrm{i}}+\mathrm{e}_{\mathrm{ij}}$

Where;

$\mathrm{Y}_{\mathrm{ij}}=$ Single Observation

$\mu_{\mathrm{i}}=$ Treatment mean

$\mathrm{G}_{\mathrm{i}}=$ effect of the treatment $(\mathrm{I}=123$ and 4$)$

$\mathrm{e}_{\mathrm{ij}}=$ random error

\section{Data collection}

Seven (7) days after administration of clomiphene citrate, data collection started and this was done based on the following: eight hens representing the treatment groups (2 from each group) were slaughtered and the primary reproductive organs taken and were weighed. Different parts of the ovarian morphology were separated and each part weighed. The ovarian biometric measurements were measured using sensitive weighing balance.

\section{Data analysis}

Data collected on ovarian morphology were subjected to Analysis of variance (ANOVA) as outlined by Steel and Torie (1980). The treatment mean were significant and separated using Ducan's New multiple Range test.

Table 1: Nigerian indigenous hen's reproduction organ weight

\begin{tabular}{|c|c|c|c|c|c|}
\hline \multirow[b]{3}{*}{ Parameters } & \multicolumn{5}{|c|}{ Treatment (clomiphene citrate) } \\
\hline & 0.00 & 10 & 20 & 30 & SEM \\
\hline & Mg & mg & mg & mg & \\
\hline Full Reproductive Organ (g) & $85.01^{\mathrm{a}}$ & $80.02^{\mathrm{b}}$ & $85.30^{\mathrm{a}}$ & $83.00^{\mathrm{b}}$ & 1.22 \\
\hline Right Oviduct (g) & $10.01^{\mathrm{a}}$ & $12.03^{\mathrm{a}}$ & $2.70^{\mathrm{b}}$ & $3.20^{\mathrm{b}}$ & 0.33 \\
\hline Left Oviduct (g) & $18.02^{\mathrm{a}}$ & $12.27^{\mathrm{c}}$ & $13.10^{\mathrm{c}}$ & $14.00^{\mathrm{b}}$ & 0.48 \\
\hline Paired Oviduct (g) & $28.03^{\mathrm{a}}$ & $24.30^{\mathrm{b}}$ & $15.80^{\mathrm{d}}$ & $17.20^{\mathrm{c}}$ & 0.52 \\
\hline Left Ovary (g) & $44.00^{\mathrm{a}}$ & $42.00^{\mathrm{b}}$ & $43.00^{\mathrm{a}}$ & $43.00^{\mathrm{a}}$ & 0.41 \\
\hline Right Ovary (g) & $6.00^{\mathrm{a}}$ & $5.00^{\mathrm{b}}$ & $5.10^{\mathrm{b}}$ & $5.30^{\mathrm{b}}$ & 0.23 \\
\hline Paired Ovary (g) & $50.00^{\mathrm{a}}$ & $47.00^{\mathrm{b}}$ & $48.10^{\mathrm{b}}$ & $48.30^{\mathrm{b}}$ & 1.15 \\
\hline Uterus $(\mathrm{g})$ & $11.00^{\mathrm{a}}$ & $9.00^{\mathrm{b}}$ & $10.00^{\mathrm{a}}$ & $9.00^{\mathrm{b}}$ & 1.00 \\
\hline Vagina $(g)$ & $5.00^{\mathrm{a}}$ & $4.00^{\mathrm{b}}$ & $5.00^{\mathrm{a}}$ & $3.00^{\mathrm{c}}$ & 0.48 \\
\hline
\end{tabular}




\section{Morphometic study of Nigerian indigenous hen treatment with clomiphene citrate (clomid ${ }^{\circledR}$ )}

\section{Results and Discussion}

Table 2 shows the reproductive organ weight of matured Nigerian indigenous hens as affected by clomiphene citrate. Significant differences $(\mathrm{P}<0.05)$ were observed among the treatment groups in the complete reproductive organ weight. Hens on $20 \mathrm{mg}$ clomiphene treatment recorded the highest value of $85.30 \mathrm{~g}$ which was significantly different $(\mathrm{P}<0.05)$ from all other treatment groups except treatment ${ }_{2}$ $\left(T_{2}\right)$. The lowest value recorded was in $T_{2}$ (10mg) which was $80.02 \mathrm{~g}$. Birds on $\mathrm{T}_{2}$ recorded the highest value of $12.0 \mathrm{~g}$ for right oviduct followed by $\mathrm{T}_{1}(10.01), \mathrm{T}_{4}(3.20 \mathrm{~g})$ and $\mathrm{T}_{3}(2.70 \mathrm{~g})$ respectively. There was no significant differences $(\mathrm{P}>0.05)$ between $\mathrm{T}_{1}$ and $T_{2}$ which differed significantly $(\mathrm{P}<0.05)$ from $\mathrm{T}_{3}$ and $\mathrm{T}_{4}$. The left oviduct is more pronounced and functional than the right oviduct. Birds on the control treatment recorded the highest value of $(18.02 \mathrm{~g})$ in left oviduct followed by $\mathrm{T}_{4}$ (14.00g), $\mathrm{T}_{3}(13.0 \mathrm{~g})$ and $\mathrm{T}_{2}(12.27)$. These areleftoviduct is derived from the left mulleirian duct and consists of five regions; the infundibulum, the magnum, isthmus, shell gland and vagina (Johnson 1986.)

There were significant differences ( $p$ $<0.05$ ) in paired Oviduct among the treatment groups. The control treatment ranked highest $(28.03 \mathrm{~g})$ followed by $\mathrm{T}_{2}$ (24.30g), $\mathrm{T}_{4}(17.20 \mathrm{~g})$ and $\mathrm{T}_{3}(15.80 \mathrm{~g})$. All the treatment groups were significantly different $(p<0.05)$ from one another. Values recorded in this work for oviduct is in agreement with report of Barnejee (2007) that the left oviduct is more functional except on a very rare occasion, where the right oviduct can be functional. This also was in agreement with values of $22.00 \mathrm{~g}$ recorded by Alexis and Romanoff (1949) and recorded values of $22.28 \mathrm{~g}$ and $16.80 \mathrm{~g}$ gotten by Natasha and Kiril (2011). There were significant differences $(\mathrm{p}<0.05)$ in the right ovary, left ovary and paired ovary among the treatment groups. Birds on control treatment recorded the highest values of $44 \mathrm{~g}, 6 \mathrm{~g}$ and $50 \mathrm{~g}$ in left ovary, right ovary and paired ovary respectively whilethe lowest values of $42 \mathrm{~g}, 5 \mathrm{~g}$ and $47 \mathrm{~g}$ in the above mentioned parameters were recorded in $T_{2}(10 \mathrm{mg})$, which were significantly different $(\mathrm{p}<0.05)$ from $\mathrm{T}_{1}$, but were not significantly different from $\mathrm{T}_{3}$ and $\mathrm{T}_{4}$ respectively. Values obtained from left ovary were higher than values obtained in the right ovary. These values are in agreement with the report of Barnejee (2007) who reported that the left ovary is always higher than the values of right ovary and that both right ovary and right oviduct are undeveloped but on rare case this right ovary and oviduct can be only as a functionless rudiment. Ovary weight, recorded in this work fell within the range of $45.02 \mathrm{~g}$ recorded by Natasha and Kiril (2011) in Isa and Hisex brown laying hen. There were significant differences $(p<$ 0.05 ) in the uterus among the treatment groups. Birds on the control recorded the highest value of $11.00 \mathrm{~g}$, while birds on $10 \mathrm{mg}$ and $30 \mathrm{mg}$ clomiphene treatment recorded the same and lowest value of $9.00 \mathrm{mg}$. Birds on control were not significantly different from birds on $10 \mathrm{mg}$ clomiphene treatment and $30 \mathrm{mg}$ clomiphene treatment which were similar. There were significant differences $(\mathrm{p}<0.05)$ among the treatment groups in vagina. Birds on control treatment were not significantly different $(\mathrm{p}<0.05)$ from birds on $20 \mathrm{mg}$ clomiphene treatment, but were significantly $(\mathrm{p}<0.05)$ from birds on $10 \mathrm{mg}$ clomiphene treatment, and birds on $30 \mathrm{mg}$ clomiphene treatment. However, the highest values of $(5.00 \mathrm{mg})$ were recorded in the control and $20 \mathrm{mg}$ clomiphene treatment, while the lowest value in $(3.00 \mathrm{mg})$ vagina was recorded in $30 \mathrm{mg}$ clomiphene treatment birds. The result of 


\section{Urom, Dauda and Onunkwo}

this study indicated that clomiphene citrate has no negative effect on the size and weight of the reproductive organs of Nigerian indigenous birds.

\section{Conclusion}

This study revealed positive effect of clomiphene citrate on the morphometric weight of reproductive organs of Nigerian indigenous hens at $20 \mathrm{mg}$ dosage administration while, the administration at lower than $20 \mathrm{mg}$ or higher than $20 \mathrm{mg}$ do not enhance the morphometric weight. The study shows that $20 \mathrm{mg}$ inclusion of clomiphene citrate is the appropriate dosage for reproductive organ improvement in Nigerian indigenous hens.

\section{References}

Alaba, O. J, Adama, J. Y. Fasanya, O. O. A. and David, O. M. 2016. Responsible of finishing broilers chickens to diets containing human liquor fermented rice husk meal.

Charles, D., Barr, W., Bell, E. T., Brown, J. B., Forthery and Loraine, J. A. 1963. Clomiphene in the treatment of Oligomenorrhea and amenorrhea; 86:913-922

Food and agricultural organization of united Nation (FAO) 1999. Animal genetic resources information, No 25, Rome Italy.

Food and agricultural organization of united nation (FAO) 1988. Malnutrition in Africa production year book: No 35, Rome, Italy

Geoff, B. 1995. Fish married and Tuna erales "private sector fish proceeding and marketing in Ghana (in) Marketing Afiricas High value food (ed) Steve, J and john Pp. 375-416

Greenblatt, R. B., Roy, S., Mahesh, V. B., Batrfield, W. E. and Junggeck, E. C. 1962. Induction of ovulation.
Am. J. ObstetGynecol 84: 900-912.

Herbert, U., Okoro, P., Umesiobi, D. O. and iloeje, M. U. 2000. Effect of two preparation of clomiphene citratee on super - ovulation of west Ewes. $14^{\text {th }}$ international congress on animal reproduction Sweden 2:2:114

Ihekwumere, F. C, 2005. Super ovulation in Goats in AfamAnene and nwaigbo $\mathrm{L} C$ (eds). issues in substainable Agriculture in Nigeria. Osprey Publication centreOwerri, Nigeria 1-9.

Kaiser, I. H. 1963. Pregnancy following clomiphene-induced ovulation in chiari-formmel syndrome. Am. $J$. Obstet. Gynecol. 87: 149-151.

Naidhaerdt, R. 1992. Influences of general condition in livestock production of the appropriate application of biotechnology in livestock production in developing countries.Part I Franzen H. Smidi, G(Ei) Pp. 224-227

Obi, I. U. 1990. Statistical method of detecting differences between treatment means, $2^{\text {nd }}$ edition. Snaap Press, Enugu, Nigeria.

Okonkwo,W. A. and Akubuo, C. O. 2001. Ilumal analysis and evalution of heat requirement of passive energy poultry chick Broodenin Nigeria .Renewal Energy 9:1

Okoye, F. C., Omorinkoba, S. O., Ayanda, J. O. and Ita, E. O. 1991. Commercial fish farming in eastern ponds prospects and problems in ogbor.proceedings of committee of Director of research institutes $10^{\text {th }}$ December $1991 \mathrm{Pp}$. 61-70

Olayemi, J. K. 1996. Food security in Nigeria: the report of research study sponsored by development policy center 
Morphometic study of Nigerian indigenous hen treatment with clomiphene citrate (clomid ${ }^{\mathbb{B}}$ )

Ibadan, Nigeria Pp. 62.

Pereira, R. J. J. A., Sohnry, B. and Holl, W. 2000. Non-surgical collection of Goats embryo. Proc $13^{\text {th }}$ int .Congrsydney, Australia. Pp. 1823.

Riley, G. M. and Evans, T. N. 1964. Effects of Clomiphene on an ovulatory ovarian functions; Am J. Obstet. Gynecol. 8997-110.

RIM (resources inventory and management ltd) 1992. Nigeria national livestock survey. Federal department of livestock and rest control services Abuja Nigeria Pp. .28

Roy, S. and Greenblatt, R. B. 1964. Effects of Clomiphene on the physiology of reproductions in rat. II. its oestrogenic and antiestrogenic actions $A$ c $t$ a E n d o c r $i$ n o l (Copenhagen)47 657-668.
Steel, R. G. D. and Torrie, J. H. 1980. Principles and procedure of statistics. A Biometric approach $2^{\text {nd }}$ Edition. Mc. Graw-Hill Books Co. Inc New York.

Teriblance, S. J. and Hunton T. 2000. Effect of fluxinemeglumine or and plasma concentration $\mathrm{o} f$ androgens and leutinizing hormone during sexual development in the cockerel .J. endocrinal, 74: 457-469.

Whitelaw, M. J. 1963. Clomiphene citrate: Newer aspects of its use in prevention and treatment of infertility; fertile. Steril. 14 540546
Received: $25^{\text {th }}$ August, 2016 Accepted: 12 $2^{\text {th }}$ March, 2017 